Journal of Applied Pharmaceutical Science Vol. 4 (10), pp. 001-006, October, 2014

Available online at http://www.japsonline.com

DOI: 10.7324/JAPS.2014.401001

ISSN 2231-3354 (cc)) BY-NC-SA

\title{
Prodigiosin - an antibacterial red pigment produced by Serratia marcescens IBRL USM 84 associated with a marine sponge Xestospongia testudinaria
}

\author{
Darah Ibrahim ${ }^{1}$, Teh Faridah Nazari ${ }^{1}$, Jain Kassim ${ }^{2}$, Sheh-Hong Lim ${ }^{1}$ \\ ${ }^{1}$ Industrial Biotechnology Research Laboratory, School of Biological Sciences, ${ }^{2}$ School of Chemical Sciences, Universiti Sains Malaysia, 11800 Penang, \\ Malaysia.
}

\section{ARTICLE INFO}

Article history:

Received on: 29/06/2014

Revised on: 17/07/2014

Accepted on: 22/08/2014

Available online: $30 / 10 / 2014$

\section{Key words:}

Serratia marcescens; Xestospongia testudinaria;

prodigiosin; antibacterial

activity.

\begin{abstract}
The objectives of present study are to extract the antibiotic compound from marine isolate and to determine its in vitro antimicrobial activity against bacteria. A marine bacterial isolate Serratia marcescens IBRL USM 84 was isolated from the surface of a marine sponge Xestospongia testudinaria. This species of bacteria produced red pigment with antibacterial activity. The red antibacterial pigment was produced intracellularly and inhibited 13 out of 18 tested bacteria, with Gram positive was more susceptible than the Gram negative bacteria. The growth and antibacterial red pigment production profiles demonstrated the highest antibacterial red pigment production was achieved at the 48 hours of cultivation $(14.08 \mathrm{U} / \mathrm{ml})$ time in marine broth when incubated at $25{ }^{\circ} \mathrm{C}$ with 150 rpm agitation. The antibacterial red pigment was extracted, purified and confirmed as prodigiosin.
\end{abstract}

\section{INTRODUCTION}

The increasing numbers in bacterial resistance to a number of antimicrobial agents is becoming a major health problem worldwide. Besides, the increasing use and misuse, of existing antibiotics in human, veterinary medicine and in agriculture has further aggravated the problem (Todar, 2004). Common species among them are methicillin-resistant Staphylococcus aureus (MRSA), penicillin-resistant Streptococcus pneumoniae, vancomycin-resistant Enterococcus and Mycobacterium tuberculosis (Barrett and Barrett, 2003; Dancer, 2008). It is further stated that, about $70 \%$ of the bacteria that cause infections in hospitals are resistant to at least one of the drugs most commonly used for treatment (Todar, 2004). Thus, there is an urgent need for the discovery of new classes of antimicrobial compounds to overcome existing resistance mechanisms and to effectively combat these human pathogens that can cause lifethreatening infections. The importance of terrestrial microbes

\footnotetext{
* Corresponding Author

Sheh-Hong Lim,

Email:limshehhong77@gmail.com.

Tel.: +6012-4629487, Fax: +604-6565125
}

including bacteria as sources of valuable secondary bioactive metabolites is very well established and over 120 of the most important antibiotics in use today are obtained from terrestrial microorganisms (Alanis, 2005). Along with the deep studies of marine natural products biosynthesis, some evidence indicates that many bioactive compounds previously found in marine animals and plants were in fact produced or metabolized by associated microorganisms (Rinehart, 2000; Osinga et al., 2001). Competition among microbes for space and nutrient in marine environment is a powerful selection pressure that endows marine microorganisms to possess many natural products, pharmaceutical and industrial values (Armstrong et al., 2001). Recently many reports have been published on the production of potential antimicrobial compounds from marine bacteria associated with sponges, macroalgae and invertebrates. The first antibiotic from marine bacterium was identified and characterized in 1966 (Burkholder et al., 1966). Sponges are the most primitive of multi-celled animals and have existed for more than 800 million years (Radjasa et al., 2007). They are known to produce secondary metabolites which play a decisive ecological role, protecting them against potential invaders, predators or other competitors (Pawlik et al., 2002). 
Bacteria growing on the surface of sponges live in a highly competitive environment in which access to space and nutrients are limited (Burgess et al., 1999; Slattery et al., 2001). Secondary metabolites produced by sponge-associated bacteria far exceed those produced by planktonic bacteria (Lu et al., 2009). Several potentially therapeutic compounds identified in sponges have striking similarities to metabolites derived from their associated microorganisms (Radjasa et al., 2007; Thiel and Imhoff, 2003). Hence, sponge-associated bacteria become a highly potential source for the production of antibiotic compounds.

The aim of the present study was to extract the red pigment from culturable marine bacteria associated with a marine sponge Xetospongia testudinaria and to evaluate its antibacterial activity against a series of microorganisms.

\section{MATERIALS AND METHODS}

\section{Culture maintenance}

Bacterial isolate IBRL USM 84 was isolated from the surface of a local marine sponge, X. testudinaria which was collected from Bidong Island, Terengganu, Malaysia. This isolate was supplied by the Industrial Biotechnology Research Laboratory, School of Biological Sciences, Universiti Sains Malaysia. The bacterial culture was maintained on the marine agar (Difco, United Kingdom) slant at $25{ }^{\circ} \mathrm{C}$ for 72 hours before storing at $4{ }^{\circ} \mathrm{C}$ for subsequent studies. The stored bacterial culture was subcultured regularly at every month to maintain viability.

\section{Cultivation, extraction of the crude extract and cellular distribution of antibacterial compounds in the isolate IBRL USM 84 cell}

Ten colonies of the isolate IBRL USM 84 were inoculated in to $250 \mathrm{ml}$ Erlenmeyer flask containing $50.0 \mathrm{ml}$ of marine broth medium (Difco, United Kingdom) and incubated at $25^{\circ} \mathrm{C}$ with $150 \mathrm{rpm}$ of agitation for 72 hours. The culture was then separated by centrifugation at $5,000 \mathrm{~g}$ (Sigma 42k, Sartorius, Germany) for 20 minutes at $4{ }^{\circ} \mathrm{C}$. The supernatant was tested for extracellular antibacterial activity using disc diffusion susceptibility test.

The pellet was washed twice with $0.85 \%$ (w/v) physiological saline for 30 minutes and recentrifuged at $5000 \mathrm{~g}$ for 20 minutes. The washed cell pellets were then soaked in $50.0 \mathrm{ml}$ sterile distilled water for an hour at $4{ }^{\circ} \mathrm{C}$ to give osmotic shock condition to the cells. The cells were broken up by adding 10 sterile glass beads $(0.4 \mathrm{~mm}$ diameter $)$ and vigorously agitated using vortex (Donna and Nicholas, 1997). The suspension was then separated by centrifugation at $5,000 \mathrm{~g}$ for 20 minutes at $4{ }^{\circ} \mathrm{C}$. The resultant cell suspension after cell disruption was centrifuged and the supernatant was tested for intracellular antibacterial activity. The test bacteria used in this experiment was MRSA. The results were expressed as mean value \pm standard error of the inhibition zone obtained with three replicates for each experiment.

\section{Test microorganism}

Eighteen bacterial cultures such as Acinetobacter anitratus, Agrobacterium tumefaciens, Azotobacter sp., Bacillus licheniformis, Bacillus cereus, Bacillus subtilisBacillus thuringiensis, Citrobacter freundii, Erwinia sp., Escherichia coli, Micrococcus sp., Methicillin resistant Staphylococcus aureus (MRSA), Proteus rettgeri, Salmonella parathypi, Staphylococcus epidermidis, Staphylococcus saprophyticus, Staphylococcus aureus and Yersinia sp. provided by the Industrial Biotechnology Research Laboratory, School of Biological Sciences, USM, were used as test bacteria in this study. The culture was grown on nutrient agar (Merck, Germany) and incubated at $37{ }^{\circ} \mathrm{C}$ for 24 hours before storing them at $4{ }^{\circ} \mathrm{C}$ until further use. The stored bacterial culture was subcultured regularly at every month to maintain viability.

\section{Inoculum preparation}

Inoculum was prepared by inoculating five colonies from $>24$ hour old of bacterial culture into a universal bottle containing $5.0 \mathrm{ml}$ of Tripcase Soy broth and incubated for 6 hours. The logarithmic phase culture was adjusted to yield a cell density of approximately $1 \times 10^{8}$ colony forming unit per $\mathrm{ml}(\mathrm{cfu} / \mathrm{mL})$ as described in Clinical and Laboratory Standards institute (CLSI) standard M26-A (NCCLS 1998).

\section{Disc diffusion susceptibility test}

The assay was performed according to the CLSI standard M2-A9 (NCCLS, 1998) with slight modifications. Using a sterile cotton swab, tested bacterial inoculum of approximately $1 \times 10^{8}$ $\mathrm{cfu} / \mathrm{ml}$ was streaked onto the surface of a Soy Tripcase agar plate. Sterile Whatman antibiotic discs $(6.0 \mathrm{~mm}$ diameter $)$ impregnated with $20 \mu \mathrm{l}$ of supernatant were then placed on the surface of the inoculated medium. Distilled water was applied as a negative control and $30 \mu \mathrm{g} / \mathrm{ml}$ of chloramphenicol was used as a positive control. The plates were incubated at $37{ }^{\circ} \mathrm{C}$ for 24 hours and the diameter of the clear zone was measured. The results were expressed as mean value \pm standard error of the inhibition zone obtained with three replicates for each experiment.

\section{Determination of antibacterial activity secreted by the isolate IBRL USM 84 against MRSA growth}

The amount of antibacterial activity secreted by the isolate was measured quantitatively using the method described previously by Lorian (1991). About $0.1 \mathrm{ml}$ of the $>24$ hour old MRSA cell suspension $\left(3-4 \times 10^{5}\right.$ cells $/ \mathrm{ml}$ ) was inoculated in 7.9 $\mathrm{ml}$ nutrient broth followed by the addition of $2.0 \mathrm{ml}$ intracellular extraction of the isolate Serratia marcescens IBRL USM 84 obtained from different cultivation time. The mixture was then incubated at $37^{\circ} \mathrm{C}$ for 14 hours. The degree of inhibition of the test bacteria (MRSA) was determined based on the decrease in the culture turbidity measured spectrophotometrically (Spectronic Unicam, United State) at $560 \mathrm{~nm}$, compared to control. The control consisted the same material as for the test culture but with no addition of the isolate Serratia marcescens IBRL USM 84 
cultivation broth, instead it was replaced by addition of another 2.0 $\mathrm{ml}$ of nutrient broth. To facilitate the expression of the potency of the antibacterial activity of the compounds secreted by the isolate Serratia marcescens IBRL USM 84, the antibacterial activity was defined as one unit (U) of the antibacterial activity which resulted the reduction or inhibition of $1.0 \%$ on the growth of MRSA in the liquid medium which was used as the test microorganism.

\section{Serratia marcescens IBRL USM 84 Cell growth determination}

The cell growth was determined spectrophotometrically (Spectronic Unicam, Genesys 10UV, United State)) at $540 \mathrm{~nm}$ and the actual concentration was compared to standard curve prepared prior determination.

\section{Extraction, purification and identification of prodigiosin}

The red pigment produced by the isolate Serratia marcescens IBRL USM 84 was extracted and analyzed by method of Cang et al., (2000) and Allihoesseni et al., (2008). Three milliliter of acetone was added into $1.0 \mathrm{ml}$ of a thick IBRL USM 84 cell suspension and agitated at $150 \mathrm{rpm}$ for 30 minutes at room temperature $\left(30 \pm 2{ }^{\circ} \mathrm{C}\right)$.

The mixture was centrifuged at $5000 \mathrm{~g}$ for 20 minutes. The red colored supernatant was mixed with petroleum ether with the ratio of 1:2 in a separating funnel and shook vigorously until the red pigment was in the petroleum ether. The extracted red colored petroleum ether solution was evaporated using a rotary evaporator under reduced pressure until the dried red pigment obtained and was used for spectral analysis.

Fifty microgram of dried red pigment was dissolved in $10.0 \mathrm{ml}$ of absolute ethanol and in order to get an acidic condition, $1.0 \mathrm{ml}$ of $1.0 \mathrm{M} \mathrm{HCl}$ was added into the solution. To get an alkaline solution, $1.0 \mathrm{ml}$ of $1.0 \mathrm{M} \mathrm{NaOH}$ was added and to get a neutral condition $1.0 \mathrm{ml}$ of sterile distilled water was added into the solution. A spectral analysis of the pigment in acidic, alkaline and neutral solution was determined using a spectrophotometer (Spectronic Unicam, Genesys 10UV, United State) at 400-600 nm.

\section{Statistical analysis}

The significant difference of the mean data was analyzed using one way Analysis of variance (ANOVA) and Duncan test with PASW Statistics 18 version.

\section{RESULTS}

Antibacterial activity of the intracellular compounds of Serratia marcescens IBRL USM 84

The antibacterial activities of the test bacterial strains studied are presented in Table 1. The commercial antibiotics chloramphenicol has shown significantly $(\mathrm{P}>0.05)$ larger inhibition zone compared to the intracellular extract of Serratia marcescens IBRL USM 84. The red pigment intracellular extract of Serratia marcescens IBRL USM 84 exhibited a broad inhibitory spectrum activity against 13 out of 18 test bacteria. These results are supported by Figure 1 where it shows the present of the

antibacterial pigment in the cells. The intracellular antibacterial pigment production is higher as the incubation time increased from 48 (Fig. 1a) to 72 hours (Fig. 1b). However, it was noted that all the test bacteria were resistant to the extracellular extract treatment.

MRSA produced the largest diameter inhibition zone $22.5 \mathrm{~cm}$ (data not shown) in agar disc diffusion assay test and it is also a pathogenic bacteria which commonly causes of nosocomial infections was chosen for further study.

A

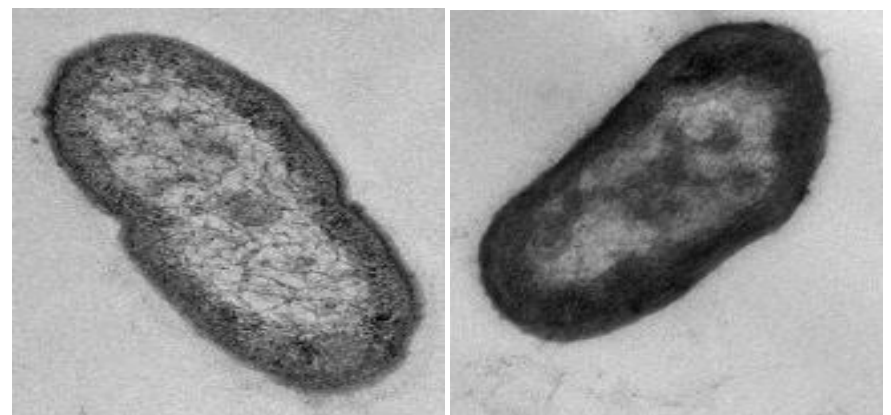

Fig. 1: TEM micrographs of the Serratia marcescens IBRL USM 84 cells. (A) 48 hours and (B) 72 hours of incubation at $25^{\circ} \mathrm{C}$.

Table 1: Antimicrobial activity of cellular distribution of antibacterial compounds extracted from Serratia marcescens IBRL USM 84.

\begin{tabular}{lccc}
\hline \multirow{2}{*}{ Test microorganisms } & \multicolumn{3}{c}{ Inhibition zone (mm) } \\
\cline { 2 - 4 } & I & E & C \\
\hline Acinetobacter anitratus - & + & - & ++ \\
Agrobacterium tumefaciens & ++ & - & +++ \\
Azotobacter sp. & - & - & ++ \\
Bacillus licheniformis & ++ & - & +++ \\
Bacillus cereus & ++ & - & ++ \\
Bacillus subtilis & + & - & +++ \\
Bacillus thuringiensis & + & - & ++ \\
Citrobacter freundii & - & - & ++ \\
Erwinia sp. & + & - & ++ \\
Escherichia coli - & + & - & ++ \\
Micrococcus sp. & + & - & ++ \\
Methicillin resistant Staphylococcus & +++ & - & +++ \\
aureus (MRSA) & & & \\
Proteus rettgeri & - & - & ++ \\
Salmonella parathypi & - & - & ++ \\
Staphylococcus epidermidis & + & - & ++ \\
Staphylococcus saprophyticus & + & - & +++ \\
Staphylococcus aureus & + & - & +++ \\
Yersinia sp. & - & - & ++ \\
\hline Not The antimicrobial activity & & & + \\
\hline
\end{tabular}

Note: The antimicrobial activity was determined based on the diameter of inhibition zone $(\mathrm{mm})$. The results were recorded according to following scale: $+++=\geq 15 \mathrm{~mm},++=10-14 \mathrm{~mm},+=\leq 9 \mathrm{~mm},-=$ no inhibition zone. $\mathrm{I}=$ Intracellular extract of Serratia marcescens IBRL USM 84, E= Extracellular extract of Serratia marcescens IBRL USM 84, C = Chloramphenicol.

\section{Profile of antibacterial red pigment production by Serratia marcescens IBRL USM 84 against MRSA}

Figure 2 shows the profile of antibacterial red pigment produced by Serratia marcescens IBRL USM 84 in 72 hours of cultivation in marine broth medium. The antibacterial activity was detected at 8 hours $(4.41 \mathrm{U} / \mathrm{ml})$ of cultivation and increased gradually and achieved it maximal value of $14.08 \mathrm{U} / \mathrm{ml}$ at the 48 hours of cultivation. The activity was then decreasing slowly thereafter until 72 hours of cultivation. The growth of Serratia 
marcescens IBRL USM 84 also follow the same pattern as the antibacterial activity and achieved its maximal growth of $2.10 \mathrm{~g} / \mathrm{L}$ at the 48 hours of cultivation.

These results suggested that the antibacterial red pigment production is growth dependent. There was a slight increased in $\mathrm{pH}$ of the medium from 7.5 at the beginning of the cultivation to 9.6 at 72 hours of cultivation showing that the bacterial cells need an alkaline condition to produced the antibacterial activity significantly.

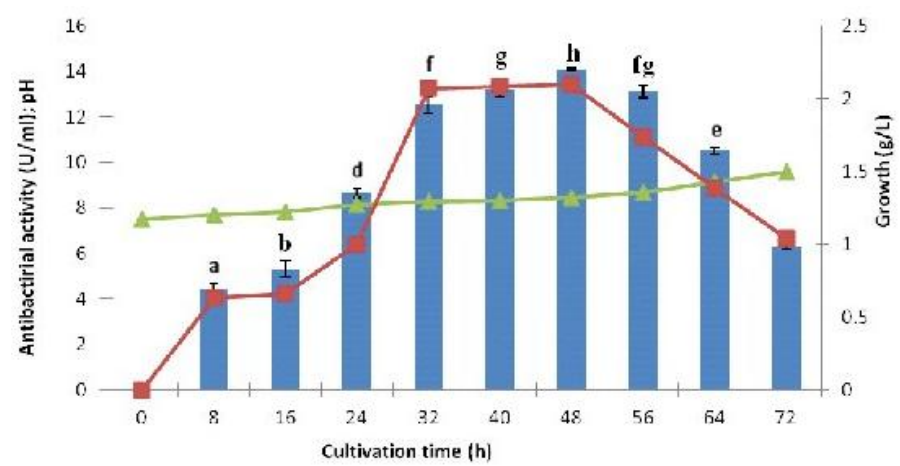

Fig. 2. Profiles of antibacterial red pigment production and cell growth of Serratia marcescens IBRL USM 84.

Note: $\mathrm{pH}$; antibacterial activity; $\rightarrow$ growth. (Error bars refer to standard deviation calculated from the triplicate samples. Means with different letters indicated significantly different at $\mathrm{p} \leq 0.05$, Duncan test).

\section{Identification of red pigment}

The red pigment displayed maximum absorbance at 465 $\mathrm{nm}$ wavelengths under alkaline conditions and at $535 \mathrm{~nm}$ under acid conditions (Fig. 3).

In acidic condition, the pigment is red, symmetrical narrow band with a peak at $535 \mathrm{~nm}$ and a slight shoulder on the lower wavelength limb of the curve. In alkaline solution, the pigment is orange-yellow due to a broader, less intense, roughly symmetrical band centered at about $465 \mathrm{~nm}$. There appears to be a definite isobestic point at about $495 \mathrm{~nm}$. Maximum absorption spectrum of the prodigiosin produced by Serratia marcescens IBRL USM 84 was in accordance with the literature (Williams, 1973).

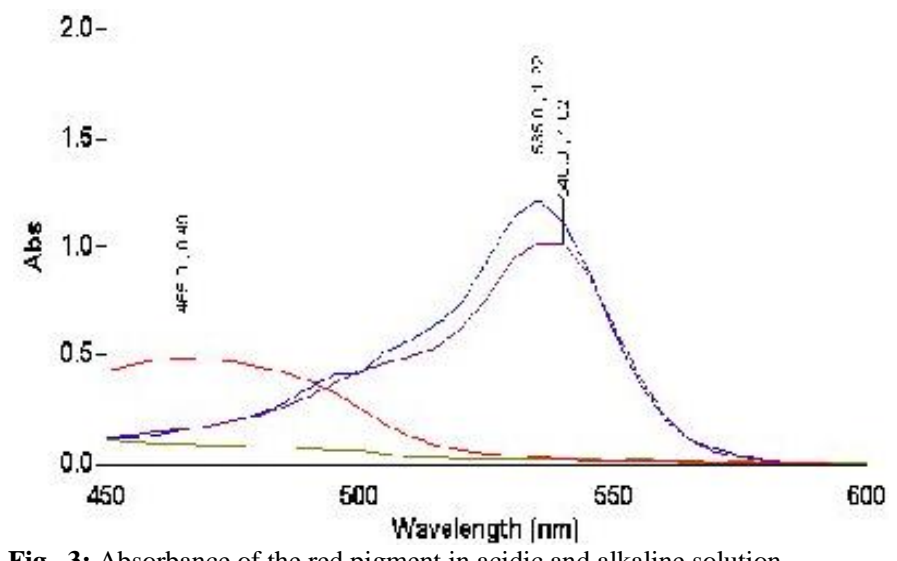

Fig. 3: Absorbance of the red pigment in acidic and alkaline solution.

Note alkaline medium $(\mathrm{NaOH}$ and ethanol); acidic medium ( $\mathrm{HCl}$ and ethanol); __ neutral medium (water and ethanol)

\section{DISCUSSION}

The main and most plentiful pigment group in marine pigmented bacteria is carotenoid which usually appears orange, yellow or red in colour (Marit et al., 2010). The pigment also exhibits antimicrobial including antibacterial activity (Gulani et al., 2012).

Serratia marcescens IBRL USM 84 was isolated from the surface of a marine sponge and its red pigment which was confirmed as prodigiosin exhibited antibacterial activity. Marine sponges are reported as rich sources of natural compounds, which exhibit wide variety of biological activity (De Rosa et al., 2003). Hence, many novel microorganisms with potential biological activity were isolated from marine sponges (Hentschel et al., 2001; Devi et al., 2010). Moreover, the numbers of bacteria associated with marine sponges are two or three times higher than seawater because of the specific surface and internal environmental niche of sponges (Friedrich et al., 2001).

Marine bacterial isolates have been proven to contain active compounds, prodigiosin (red pigment), violacein (violet pigment) and pyocianin (blue-green pigment) that are known to have active compounds such as anitimicrobial activity, antiviral, antitumor, antiprotozoa, antioxidant, anticancer and much more (kim et al., 2010; Solieve et al., 2011) However, red pigment has higher antimicrobial especially antibacterial activity followed by orange, yellow and green (Solieve et al., 2011). Among marine bacteria that have been reported to produce red pigment with prodigiosin or antibacterial activity are Serratia marcescens (Solieve et al., 2011) Streptomyces sp. (Gerber, 1975), Pseudomonas sp. (Gandhi et al., 1976), Pseudoalteromonas sp. (Fehér et al., 2008), Paracoccus sp. (Lee et al., 2004) and Vibrio sp. (Kumar and Nair, 2007).

The production of red pigment by Serratia marcescens IBRL USM 84, a non-clinical strain is scientifically important because there might be a relationship or correlation between pigment productions to the absence of plasmid that was also reported by Gargallo-Viola (Gargallo-Viola, 1989). Thus, pigment production by non-clinical strains of Serratia marcescens was of interest for further studies to determine a relationship, if any, of loss of pigment production to pathogenicity (Hardjito and Colwell, 2002).

Serratia marcescens IBRL USM 84 produced intracellular antibacterial red pigment prodigiosin which showed higher susceptibility against Gram positive than Gram negative bacteria. This may be attributed to the fact that these two groups differ in their structure of the cell wall components. The same characteristics were observed in other antimicrobial studies of plant extract against pathogenic bacteria (Darah et al., 2013; Tong et al., 2014) Various studies were reported to investigate the mechanism of actions involved in bacterial killing process. Among them are the interactions of antibacterial compound with the cell membrane (Hyldgaard et al., 2012).

A Gram negative cell wall consists of lipopolysaccharide that can act as toxin to protect bacteria against predator (Barnett, 
1992). The component of lipopolysaccharide can also makes the cell wall impermeable to lipophilic solutes (Pandey, 2004), hence gives more protection in Gram negative bacteria. The cell wall of Gram-positive bacteria has a thick layer of peptidoglycan and should be more susceptible because not an effective permeability barrier (Pandey, 2004). The pigmented marine natural products can also contribute to a variety of applications, from health, cosmetic up to the flavours of food additives, paint industry, fabric dye, and ink manufacture. Thus, the variety application of marine pigment has made it as an interesting subject of investigation in scientific knowledge.

\section{CONCLUSION}

A marine sponge associated bacterial isolate Serratia marcencens IBRL USM 84 was found to produce significant intracellular antibacterial red pigment which was confirmed as prodigiosin. It inhibited a series of test bacteria and Gram positive was more susceptible than Gram negative bacteria. To the best of our knowledge, this is the first report concerning the isolation of a marine sponge associated bacterial isolate, Serratia marcencens IBRL USM 84 which has a potential to produce prodigiosin . Thus, the further study was to optimize the intracellular antibacterial red pigment production and to characterize it properties which can contribute to a variety of applications in different field of industries.

\section{ACKNOWLEDGEMENTS}

The authors would like to thank Universiti Sains Malaysia for financing this study under RUI research grant with the account number: 1001/PBIOLOGI/815098, and also to Ministry of Science, Technology and Innovation of Malaysia for financial support to Teh Faridah Nazari under MyBrain PhD.

\section{REFERENCES}

Al-Adham ISI, Dinning AJ, Eastwood IM, Austin P, Collier PJ. Cell membrane effects of some common biocides. J Ind Microbiol Biotechnol, 1998; 21: 6-10. doi: 10.1038/sj.jim.2900554.

Alanis AJ. Resistance to antibiotics: are we in the postantibiotic era? Archives Med Res, 2005; 36(6): 697-705. doi: 10.1016/j.arcmed.2005.06.009.

Alihosseini F, Ju KS, Lango J, Bruce D, Sun HG. Antibacterial colorants: Characterization of prodiginines and their applications on textile materials. Biotechnol Progress 2008; 24: 742-747. doi: 10.1021/bp070481r.

Armstrong E, Yan L, Boyd KG, Wright PC, Burgess JG. The symbiotic role of marine microbes on living surfaces. Hydrobiologia 2001; 461: 37-40. doi.org/10.1023/A:1012756913566.

Barnett M. 1992. Microbiology Laboratory Exercises: Complete Version, 2nd Edn. Brown Publishers, Dubuque: Wm. C; 1992. p. 114.

Barrett CT, Barrett JF. Antibacterials: are the new entries enough to deal with the emerging resistance problems? Current Opinion Biotechnol 2003; 14(6): 621-626. doi:10.1016/j.copbio.2003.10.003.

Burgess JG, Jordan EM, Bregu M, Mearns-Spragg, Boyd KG. Microbial antagonism: A neglected avenue of natural products research. J Biotechnol 1999; 70: 27-32. doi: 10.1016/S0168-1656(99)00054-1.

Burkholder PR, Pfister RM, Leitz FH. Production of a pyrrole antibiotic by a marine bacterium. Appl Microbiol 1966; 14: 649-653.
Cang S, Sanada M, Johdo O, Ohta S, Nagamatsu Y, Yoshimoto A. High production of prodigiosin by Serratia marcescens grown on ethanol. Biotechnol Lett 2000; 22: 1761-1765. doi: 10.1023/a:1005646102723.

Dancer ST. The effect of antibiotics on methicillin-resistant Staphylococcus aureus. J Antimicrob Chemotherapy 2008; 61: 246-253. doi: 10.1093/jac/dkm465.

De Rosa S, Mitova M, Tommonero G. Marine bacteria associated with sponges as a sources of cyclic peptides. Biomol Eng 2003; 20: 311-316. doi: 10.1016/S1389-0344(03)00038-8.

Devi P, Wahidullah S, Rodrigues C, Souza LD. The sponge associted bacterium Bacillus licheniformis SAB1: A source of antimicrobial compounds. Marine Drugs 2010; 8: 1203-1212. doi: $10.3390 / \mathrm{md} 8041203$.

Donna DS, Nicholas AJ. Cell disruption of Escherichia coli by glass bead stirring for the recovery of recombinant proteins. Analy Biochem 1997; 248: 300-301. doi: 10.2144/0000113924

Fehér D, Barlow RS, Lorenzo PS, Hemscheidt TK. A 2substituted prodiginine, 2-(p-hydroxybenzyl) prodigiosin, from Pseudoalteromonas rubra. J Nat Products 2008; 71(11): 1970-1972. doi: $10.1021 / \mathrm{np} 800493 \mathrm{p}$.

Friedrich AB, Fischer I, Proksch P, Hacker J, Hentschel U. Temporal variation of the microbial community associated with the Mediterranean sponge Aplysina aerophoba. FEMS Microbiol Ecol 2001; 38: 105-113. doi: 10.1016/S0168-6496(01)00185-4

Gandhi NM, Patell JR, Gandhi R, De Souza NJ, Kohl H. Prodigiosin metabolites of a marine Pseudomonas species. Marine Biol 1976; 34(3): 223-227. doi: 10.1007/BF00388799.

Gargallo-Viola D. Enzyme polymosphism, prodigiosin production and plasmid fingerprints in clinical and naturally occurring isolates of Serratia marcescens. J Clin Microbiol 1989; 27: 860-868.

Gerber NN. Prodigiosin-like pigments. Critical Rev Microbiol 1975; 3(4): 469-485. doi:10.3109/10408417509108758.

Gulani C, Bhattacharya S, Das A. Assessment of process parameters influencing the enhanced production of prodigiosin from Serratia marcescens and evaluation of its antimicrobial, antioxidant and dyeing potentials. Malaysian J Microbiol 2012; 8(2): 116-122.

Hardjito L, Huq A, Colwell RR. The influence of environmental conditions on the production of pigment by Serratia marcescens. Biotechnol. Bioprocess of England 2002; 7: 100-104. doi: 10.1007/BF02935887.

Hentschel U, Schmid M, Wagner M, Fieseler L, Gerrium C, Hacker J. Isolation and phylogenetic analysis of bacteria with antimicrobial activities from the Mediterranean sponge Aplysina aerophoba and Aplysina cavernicola. FEMS Microbiol Ecol 2001; 35: 305-312. doi: 10.1111/j.1574-6941.2001.tb00816.x.

Hyldgaard M, Mygind T, Meyer RL. Essential oils in food preservation: mode of action, synergies, and interactions with food matrix components. Frontiers in Microbiol 2012; 3: 12 . doi: 10.3389/fmicb.2012.00012.

Kumar NR, Nair S. Vibrio rhizosphaerae sp. nov., a redpigmented bacterium that antagonizes phytopathogenic bacteria. Int $\mathrm{J}$ Systematic Evolutionary Microbiol 2007; 1(1): 2241-2246. doi: 10.1099/ijs.0.65017-0.

Lee JH, Kim YS, Choi TJ, Lee WJ, Kim YT. Paracoccus haeundaensis sp. nov., a Gram-negative, halophilic, astaxanthin-producing bacterium. Int J Systematic Evolutionary Microbiol 2004; 54(5): 16991702. doi: 10.1099/ijs.0.63146-0.

Lorian V. Antibiotics in Laboratory Medicine. $3^{\text {rd }}$ edition. Baltimore: William \& Wilkins, 1991, pp. 1-100.

Lu Y, Dong X, Liu S, Bie X. 2009. Characterization and identification of a novel marine Streptomyces sp. produced antibacterial substance. Marine Biotechnol 2009; 11: 717-724. doi:10.1007/s10126009-9186-1.

Marit HS, Kjell DJ, Geir KA, Svein V, Trond EE, Per B. Isolation and characterization of marine pigmented bacteria from Norwegian Coastal waters and screening for carotenoids with UVA-Blue 
light absorbing properties. J Microbiol 2010; 48(1): 16-23. doi: 10.1007/s12275-009-0118-6.

NCCLS. Performance Standards for AntimicrobialDisk and Dilution Susceptibility Tests of Bacteria Isolated from Animals; Approved Standard. CCLS Document M31-A, NCCLS, 940 West Valley Road, Suite 1400, Wayne, Pennsylvania 19087, USA; 1998.

Osinga R, Armstrong E, Burgess JG, Hoffmann F, Reitner J, Schumann-Kindel G. Sponge-microbe associations and their importance for sponge bioprocess engineering. Hydrobiologia 2001; 461: 55-62. doi:10.1023/A:1012717200362.

Pandey B, Ghimire P, Agrawal VP. Studies on the antibacterial activity of the actinomycetes isolated from the Khumbu Region of Nepal. A paper presented in the International Conference and Great Himalayas: Climate, Health, Ecology, Management and Conservation, Kathmandu, Januar 2004; pp: 12-15.

Radjasa OK, Martens T, Grossart HP, Brinkoff T, Sabdono A, Simon M. Antagonistic activity of a marine bacterium Pseudoalteromonas luteoviolacea TAB4.2 associated with Coral Acropora sp. J Biological Sciences 2007; 7:239-246. doi:10.3923/jbs.2007.239.246.

Slattery M, Rajbhandari I, Wesson K. Competition-mediated antibiotic induction in the marine bacterium Streptomyces tenjimariensis. Microb Ecol 2001; 41: 90-96. doi 10. 1007/s002480000084.
Solieve AB, Hosokawa K, Enomoto K. Bioactive pigments from marine bacteria: applications and physiological roles. EvidenceBased Complementary and Alternative med. 2011; article ID 670349, 17 pages. doi: org/10.1155/2011/670349.

Thiel V, Imhoff JF. Phylogenetic identification of bacteria with antimicrobial activities isolated from Mediterranean sponges. Biomol Eng 2003; 20: 421-423. doi: 10.1016/S1389-0344(03)00069-8.

Todar, K. The Good, the Bad, and the Deadly. Science Magazine 2004, 1421.

Tong WY, Nurul-Zaadah J, Nurhaida Tan WN, Melati K, Latiffah Z, Darah I. Antimicrobial activity of Phomopsis sp. ED2 residing in medicinal plant Orthosiphon stamineus Benth. Annual Res Rev Biol 2014; 4(9): 1490-1501. doi: 10.9734/ARRB/2014/8060.

Williams RP. 1973. Biosynthesis of prodigisin, a secondary metabolite of Serratia marcescens. Appl Microbiol 1973; 25(3): 396-402.

\section{How to cite this article:}

Darah Ibrahim, Teh Faridah Nazari, Jain Kassim, Sheh-Hong Lim. Prodigiosin-an antibacterial red pigment produced by Serratia marcescens IBRL USM 84 associated with a marine sponge Xestospongia testudinaria. J App Pharm Sci, 2014; 4 (10): 001006. 